\title{
Uterine Extramedullary Plasmacytoma as a Primary Manifestation of Multiple Myeloma
}

\section{Plasmocitoma extramedular uterino como manifestação primária de mieloma múltiplo}

\author{
Ana Codorniz ${ }^{1}$ Renato Cunha ${ }^{2}$ Fernando Fernandes ${ }^{1}$ Maria João Pais ${ }^{3}$ Tiago Neves $^{4}$ \\ Carlos Quintana ${ }^{5}$ \\ ${ }^{1}$ Gynecology Department, Hospital do Espírito Santo de Évora, \\ Évora, Portugal \\ 2 Medical Oncology Department, Hospital do Espírito Santo de Évora, \\ Évora, Portugal \\ ${ }^{3}$ Medicine II Department, Hospital do Espírito Santo de Évora, \\ Évora, Portugal \\ 4 Orthopedics Department, Hospital do Espírito Santo de Évora, \\ Évora, Portugal \\ 5 Pathological Anatomy Department, Hospital do Espírito Santo de \\ Évora, Évora, Portugal \\ Rev Bras Ginecol Obstet 2017;39:516-520. \\ Address for correspondence Ana Codorniz, Medical Resident, \\ Serviço de Ginecologia do Hospital do Espírito Santo de Évora, \\ Largo Senhor da Pobreza, 7000-811, Évora, Portugal \\ (e-mail: codorniza@hotmail.com).
}

\begin{abstract}
Keywords

- plasmacytoma

- multiple myeloma
\end{abstract}

\section{Resumo}

\section{Palavras-chave}

- plasmocitoma

- mieloma múltiplo
The association between plasmacytomas and multiple myeloma (MM) is well-described, and in about one third of the cases of plasmacytoma the additional study will lead to the diagnosis of MM. The finding of plasmacytomas in the genital tract is extremely rare, with sparse cases described in the literature, and these cases pose a challenge regarding the optimal guidance and treatment. This paper describes a case of uterine extramedullary plasmacytoma in a 79-year-old woman with complaints of postmenopausal abnormal uterine bleeding. The complementary study led to the diagnosis of uterine plasmacytoma and, subsequently, of MM. Despite the unfavorable outcome of this case, we consider pertinent to report it because it constitutes a differential diagnosis to be taken into account in the approach of pelvic masses.

A associação entre plasmocitomas e mieloma múltiplo (MM) encontra-se bem demonstrada, e em cerca de um terço dos casos de plasmocitoma o estudo adicional conduzirá ao diagnóstico de MM. O achado de plasmocitomas no trato genital é extremamente raro, havendo um número muito limitado de casos descritos na literatura, o que dificulta concluir sobre a melhor forma de orientação e tratamento destes casos. O presente trabalho descreve um caso de plasmocitoma extramedular uterino em mulher de 79 anos estudada por queixas de hemorragia uterina anômala pós-menopáusica. O estudo complementar levou ao diagnóstico de plasmocitoma uterino e, posteriormente, de MM. Apesar do desfecho desfavorável do caso, consideramos pertinente o seu relato por se tratar de um diagnóstico diferencial a levar em consideração na abordagem de massas pélvicas. received

March 28, 2017

accepted

June 30, 2017

published online

August 23, 2017
Copyright @ 2017 by Thieme Revinter

Publicações Ltda, Rio de Janeiro, Brazil
License terms

ㄷ) (i) $\odot$ (\$)
$10.1055 / \mathrm{s}-0037-1605373$. ISSN 0100-7203. 


\section{Introduction}

Plasma cells dyscrasias refer to a group of neoplasms that is characterized by the proliferation of a monoclonal population of plasmocytes that secretes monoclonal immunoglobulins. These neoplasms may present in single or multiple lesions (solitary plasmacytomas or multiple myeloma respectively). The association between plasmacytomas and multiple myeloma (MM) is well-established, ${ }^{1}$ and in about one third of the cases the additional study of a plasmacytoma will lead to the diagnosis of MM. ${ }^{2}$ These tumors can appear in the bone or in different organs, and are classified as bone or extramedullary plasmacytomas respectively. ${ }^{3}$ Extramedullary plasmacytomas in the female genital tract are quite rare, either as solitary plasmacytomas or as part of a disseminated MM. There are few cases described in the literature, ${ }^{3-7}$ considering that $80 \%$ of extramedullary plasmacytomas arise in the head or neck, mostly in the superior respiratory and digestive tracts.

\section{Case Report}

We present a case of a 79-year-old woman, bedridden and totally dependent on other people to perform her daily activities, with a past history of breast cancer at 54 years old treated with conservative surgery followed by radiotherapy. She had no other relevant personal antecedents, made no chronic use of medications, and had no smoking or drinking habits. Her menarche occurred at 11 years old, and she had regular cycles and 1 pregnancy (with a vaginal delivery at 27 years old). There was no history of use of hormonal contraceptives, and she had spontaneous menopause at 41 years without hormonal therapy.

The patient arrived to the emergency department with complaints of postmenopausal abnormal uterine bleeding (AUB) since the previous month, with no other symptoms. Upon physical examination, there were no signs of hemodynamic instability. Upon the speculum examination, a moderate amount of necrotic tissue and blood with fetid odor was found in the vagina and through the external cervical orifice; they were sent for a histological test. The blood work was normal, with a hemoglobin level of $11.7 \mathrm{~g} / \mathrm{dL}$. The pelvic ultrasound showed a heterogenic endometrial thickening of $21 \mathrm{~mm}$, atrophic ovaries, and no adnexal masses. The histological study revealed a neoplasm with diffuse infiltration of atypical plasma cells, suggestive of myeloma. Immunohistochemistry: CD138 and CD56 positive, cytokeratins, S100, estrogen receptors, actin, desmin, CD20 and CD79a negative (-Fig. 1). The kappa and lambda light chain analysis was inconclusive. She had an antigen Ki-67 level of 60\%.

Shortly after, the patient returned to the emergency with a history of severe pain and functional disability of the right arm after brushing her teeth. Radiography identified a supracondylar pathological fracture of the right humerus, which reinforced the diagnosis hypothesis of MM. Additionally, she maintained the
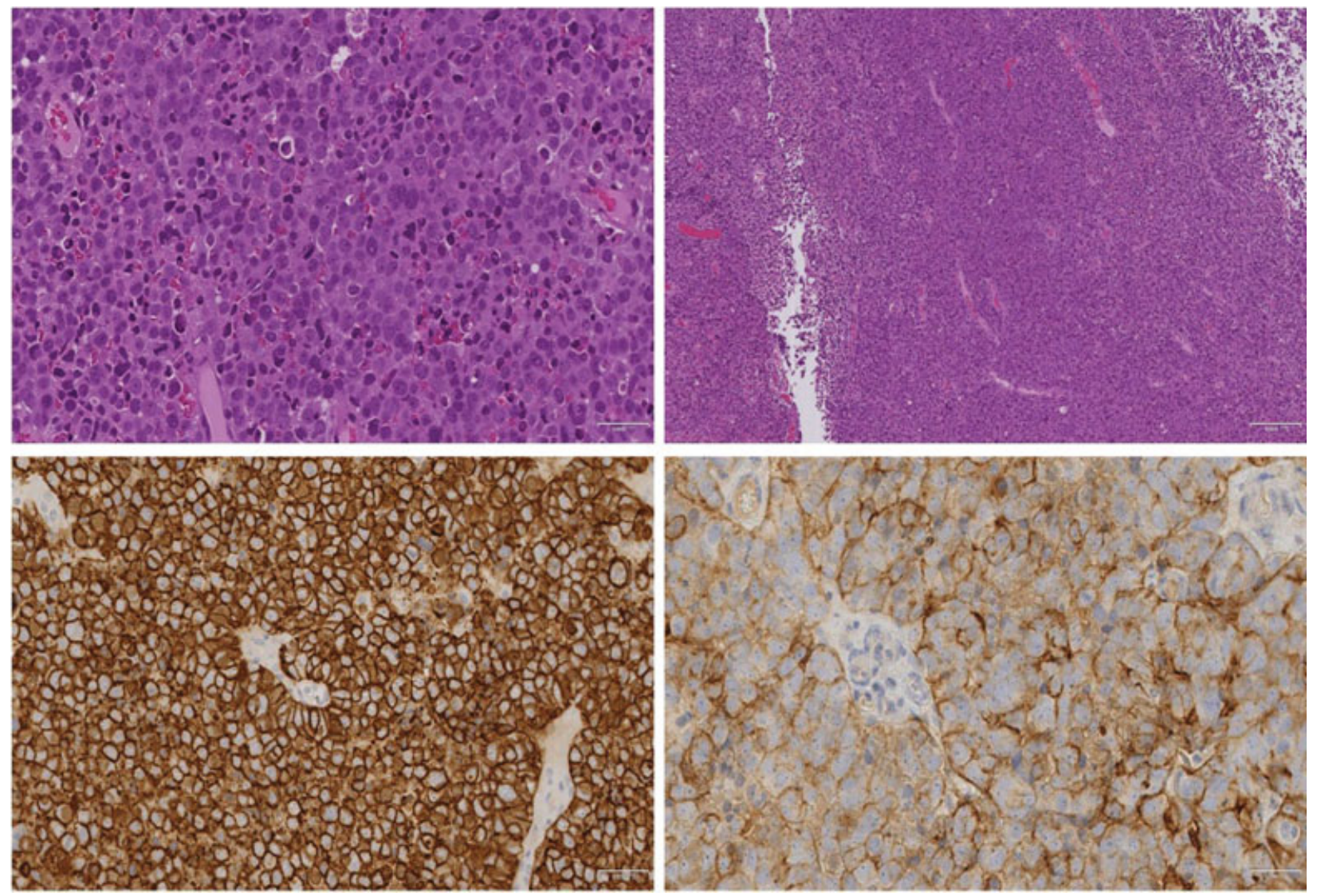

Fig. 1 Histological study of fragments of the endometrium. (A and B) Hematoxylin-eosin (HE). Immunohistochemistry with positivity for CD56 (C) and CD138 (D) antibodies. 


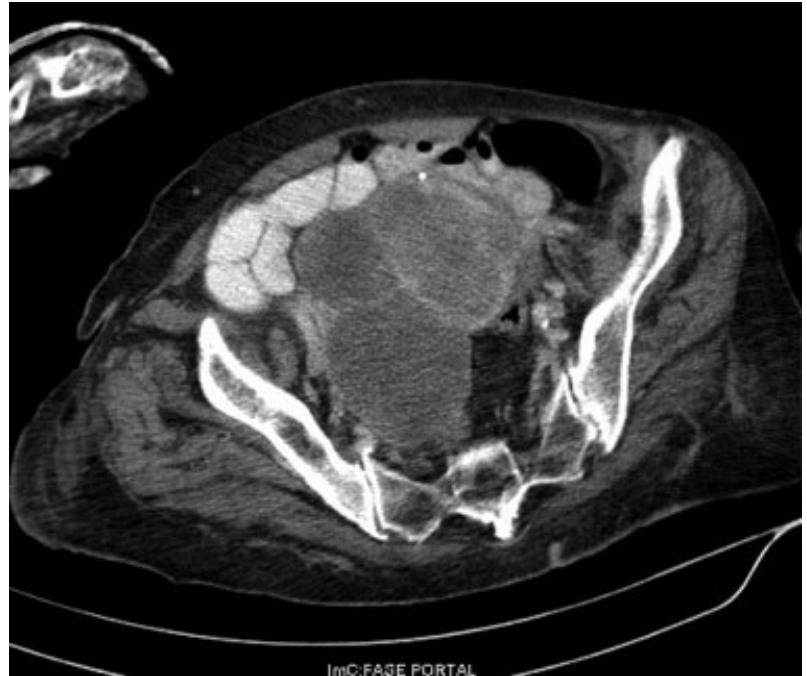

Fig. 2 Enlarged uterus with a heterogeneous uterine lesion of macrolobulated contours and intense contrast-enhanced, of probable neoformative origin.

AUB, but with associated anemia (hemoglobin level of $7.2 \mathrm{~g} / \mathrm{dL}$ ). The patient was then admitted to the Department of Orthopedics. During hospitalization and a complementary study, a rise in the $\beta$-2-microglobulin and kappa chain levels was noted. Computed tomography (CT) showed diffuse osteopenia and two expansive lesions: one with $6.9 \times 7.9 \mathrm{~cm}$, solid and heterogeneous, well-delimited, with moderate contrast-enhanced, located on the left hypochondrium, between the diaphragmatic cupula, stomach, pancreas and spleen, with apparent cleavage plan with adjacent structures; the other lesion measured $10 \times 11 \times 9 \mathrm{~cm}$, and was heterogeneous, with macrolobulated contours, and intense contrast-enhanced, located on the pelvis, probably of neoformative origin, and was responsible for an increase in the uterine volume (-Fig. 2 ).

Conservative treatment for the fracture was decided, and the patient was referred to a Hematology-Oncology appointment. In the follow-up, the diagnosis of MM was assumed, considering that the patient had a histologically-confirmed plasmacytoma, bone lesion of target organ and increase in biomarkers. However, as the patient was totally dependent, bedridden, without conditions for intensive chemotherapy regimens and presented progressive worsening of the general condition with performance status 4 at the time of the appointment, we decided to immediately start a treatment with melphalan combined with prednisolone, without waiting for other tests, namely the bone biopsy.

The patient maintained a gradual worsening of the general condition, and only had a chemotherapy cycle before dying shortly after, in a palliative care unit.

\section{Discussion}

The extramedullary and bone plasmacytomas correspond to localized forms of plasma cells neoplasms, ${ }^{8}$ and result from the proliferation of monoclonal plasma cells. ${ }^{9}$
The mean age of onset of these lesions is 55 years, with a predominance of females, ${ }^{1}$ and the most common location of extramedullary plasmacytomas is the upper respiratory and digestive tracts (82\%), followed by the gastrointestinal tract, the urogenital tract, the skin, the lung and the breast. ${ }^{10}$ The initial form of presentation may correspond to the finding of one or more localized swellings and/or the onset of nonspecific symptoms related to its location. ${ }^{11}$

The association between plasmacytomas, especially bone plasmacytomas, and MM has been well-described. ${ }^{11}$ Extramedullary involvement, however, is less frequent, and it generally presents in more advanced stages of the disease. ${ }^{12}$ Not only is there a risk of progression of solitary plasmacytomas to MM, but plasmacytomas may occur in naturally as secondary forms of $\mathrm{MM}$. $^{13}$

In less than $5 \%$ of patients with a plasma cell dyscrasia, the onset of the disease is the detection of a plasmacytoma with no manifestations of systemic disease. ${ }^{14}$ The incidence of extramedullary plasmacytomas at the time of the diagnosis of MM is around 7-18\%, and 6-20\% of patients will develop this type of tumor during the MM follow-up, ${ }^{15}$ with a better survival prognosis in the latter situation. ${ }^{1}$

The diagnosis of primary plasmacytoma (bone or extramedullary) differs from MM because there is a histological confirmation but no evidence of plasma cells involving the bone marrow, with no evidence of lytic lesions in the bone study, and absence of hypercalcemia, anemia or insufficiency associated renal disease. ${ }^{10}$

Due to its important association with MM and prognosis implications, ${ }^{10}$ the initial investigation of patients with extramedullary plasmacytoma should include a detailed study to confirm or exclude this diagnosis. ${ }^{8}$ Similarly, the follow-up of patients with the diagnosis of plasmacytoma should include adequate surveillance to allow the early detection of MM, although the duration and frequency of such follow-up have not yet been well-established. ${ }^{8}$

The occurrence of plasmacytomas in the female genital tract is rare, with few cases described. ${ }^{3-7,14,16,17}$ Due to the scarcity of available information, the optimal follow-up and treatment are also to be clarified.

Regarding the treatment, the distinction between primary plasmacytoma and MM is essential, as the approaches are quite different. While the former has a good response to radiotherapy (the first-line treatment), in the latter, the systemic treatment is the choice.

We describe a rare diagnosis of a uterine extramedullary plasmacytoma detected by postmenopausal AUB. In this case, although the complementary study was not concluded due to the rapid worsening of the general health state, the finding of bone lesions and histologically-confirmed plasmacytoma led to the diagnosis of MM. This report is relevant because it constitutes a differential diagnosis to be presented in the study of pelvic masses with important management and prognosis implications.

\section{Conflicts to Interest}

The authors have no conflicts of interest to declare. 


\section{References}

1 Schols SE, Tick LL. Recurrent extramedullary plasmacytoma in asymptomatic multiple myeloma: a case report. J Med Case Reports 2015;9:37

2 Ruiz Santiago F, Tello Moreno M, Martín Castro A, Guzmán Alvarez L, Navarrete González P. Soft tissue extramedullary plasmacytoma. Case Rep Med 2010;2010:307902

3 Fischer EG, Bocklage TJ, Rabinowitz I, Smith HO, Viswanatha DS. Primary plasmacytoma arising in an endocervical polyp with detection of neoplastic cells on papanicolaou test. A case report and review of the literature. Arch Pathol Lab Med 2003;127(01):e28-e31

4 Mondal SK, Chatterjee S, Mandal S, Bhattacharjee D. Primary extramedullary plasmacytoma of ovary: Report of a rare neoplasm. J Cancer Res Ther 2015;11(04):923-924

5 Zhong YP, Zhang JJ, Huang XN. Multiple myeloma with rupture of ovarian plasmacytoma. Chin Med J(Engl) 2012;125(16):2948-2950

6 Emery JD, Kennedy AW, Tubbs RR, Castellani WJ, Hussein MA. Plasmacytoma of the ovary: a case report and literature review. Gynecol Oncol 1999;73(01):151-154

7 Shakuntala P, Praveen S, Shankaranand B, Rajshekar K, Umadevi K, Bafna U. A rare case of plasmacytoma of the ovary: a case report and literature review. Ecancermedicalscience 2013;7:288

8 Pinto JA, Sônego TB, Artico MS, Leal CFA, Bellotto S. Extramedullary plasmacytoma of the larynx. Int Arch Otorhinolaryngol 2012; $16(3): 410-413$
9 Kilciksiz S, Karakoyun-Celik O, Agaoglu FY, Haydaroglu A. A review for solitary plasmacytoma of bone and extramedullary plasmacytoma. Sci World J 2012;2012:895765

10 Ooi GC, Chim JC, Au WY, Khong PL. Radiologic manifestations of primary solitary extramedullary and multiple solitary plasmacytomas. AJR Am J Roentgenol 2006;186(03):821-827

11 Guo SQ, Zhang L, Wang YF, et al. Prognostic factors associated with solitary plasmacytoma. Onco Targets Ther 2013;6:1659-1666

12 Huang H, Bazerbachi F, Mesa H, Gupta P. Asymptomatic multiple myeloma presenting as a nodular hepatic lesion: a case report and review of the literature. Ochsner J 2015;15(04):457-467

13 Park YM. Imaging findings of plasmacytoma of both breasts as a preceding manifestation of multiple myeloma. Case Rep Med 2016;2016:6595610

14 Huang CC, Liu MT, Pi CP, Chung CY. Primary plasmacytoma of the uterine cervix treated with three-dimensional conformal radiotherapy. Singapore Med J 2008;49(12):e361-e364

15 Bladé J, de Larrea CF, Rosiñol L. Extramedullary involvement in multiple myeloma. Haematologica 2012;97(11):1618-1619

16 Johansen B, Ahlbom G, Ostergård B. Extramedullary solitary plasmocytoma at the uterine cervix as a cause of postcoital bleeding. Acta Obstet Gynecol Scand 1989;68(03):279-280

17 Sun N, Wang L, Li W. A case of extramedullary solitary plasmacytoma arising at the uterine cervix. Eur J Gynaecol Oncol 2012; 33(04):423-424 